\title{
Climate change projection for the marsyangdi river basin, Nepal using statistical downscaling of GCM and its implications in geodisasters
}

\author{
Dibesh Khadka and Dinesh Pathak ${ }^{*}$
}

\begin{abstract}
Background: There is a very high uncertainty in the future climate change in the Himalayas and few studies has been carried out towards predicting future climate scenario in the Nepal Himalayas. In this study, climate change projection has been carried out for the Marsyangdi River Basin in the Nepal Himalaya which is focused on quantifying impacts of climate change with meteorological parameters (temperature and precipitation) for the future period, based on the outputs from fifth assessment report of Intergovernmental Panel on Climate Change. The study makes use of CanESM2 dataset which are statistically downscaled using statistical downscaling model (SDSM). Climate projections are available for three representative concentration pathways (RCPs) namely RCP 2.6, RCP 4.5 and RCP 8.5 for up to 2100.
\end{abstract}

Results: The study revealed that both the temperature and precipitation will increase for three RCPs in future. Compared to the baseline period, the annual average of maximum temperature has been projected to increase by $0.82{ }^{\circ} \mathrm{C}, 1.35^{\circ} \mathrm{C}$ and $2.29^{\circ} \mathrm{C}$ by $2090 \mathrm{~s}$, while, annual average of minimum temperature has been projected to increase by $0.87{ }^{\circ} \mathrm{C}, 1.44{ }^{\circ} \mathrm{C}$ and $2.43^{\circ} \mathrm{C}$ by 2090s for RCP 2.6, RCP 4.5 and RCP 8.5 respectively. Similarly, annual average precipitation has been projected to increase by 4,14 and $21 \%$ by 2090 s for RCP 2.6, RCP 4.5 and RCP 8.5 respectively. The projected percentage increase in annual precipitation has been found to have inverse relationship with the elevation.

Conclusions: The study suggests that climate change is evident in the study area and these findings will be useful in climate change impact assessment in different sectors such as geodisasters and future management strategies in the Marsyangdi River Basin.

Keywords: Climate change, Statistical downscaling model, Geodisaster, Marsyangdi river basin, Nepal himalayas

\section{Background}

Climate change has become a major global issue and has been receiving a serious concern at national and international levels. It is unambiguous that anthropogenic activities are responsible for continuous change of the earth's climate system, and its evidence are felt through rise in temperature, change in precipitation patterns, increase in intensity and frequency of extreme events, acceleration in melting of snow and glacier reserves over recent decades. Natural and anthropogenic substances

\footnotetext{
* Correspondence: dpathaktu@gmail.com

Central Department of Geology, Geodisaster Research Center, Tribhuvan University, Kirtipur, Kathmandu, Nepal
}

and processes that alter the Earth's energy budget are driving force of climate change. Radiative forcing (RF) which quantifies the change in energy fluxes caused by changes in these driving forces, if positive leads to warming and if negative leads to cooling. The total anthropogenic RF for 2011 relative to 1750 is 2.29 [1.13 to 3.33] $\mathrm{W} / \mathrm{m}^{2}$, and it has increased more rapidly since 1970 than during prior decades. According to IPCC fifth Assessment Report (AR5), total anthropogenic RF best estimate for 2011 is $43 \%$ higher than that reported in the fourth Assessment Report (AR4), published in 2007 (IPCC 2013).
Springer Open

(c) 2016 The Author(s). Open Access This article is distributed under the terms of the Creative Commons Attribution 4.0 International License (http://creativecommons.org/licenses/by/4.0/), which permits unrestricted use, distribution, and reproduction in any medium, provided you give appropriate credit to the original author(s) and the source, provide a link to the Creative Commons license, and indicate if changes were made. 
Nepal has also not remained aloof from impacts of climate change. Nepal has been identified as one of four global hotspots for climate change risk which is a result of complex and extreme topography, quick responding catchments with intense seasonal and climatic variability (MoSTE 2014). A study by Organization of Economic Cooperation and Development (OECD) suggests that mean annual temperature in Nepal is projected to increase by $1.2{ }^{\circ} \mathrm{C}, 1.7{ }^{\circ} \mathrm{C}$ and $3{ }^{\circ} \mathrm{C}$ for 2030,2050 and 2100 respectively, compared to baseline period of 1961-1990 (WWF 2005). Similarly, annual precipitation is projected to increase by 5,7 and $12 \%$ for the same periods. NCVST (2009) suggested that mean annual temperature across Nepal is projected to increase by $0.5-2{ }^{\circ} \mathrm{C}$ by $2030 \mathrm{~s}$; $1.7-4.1{ }^{\circ} \mathrm{C}$ by 2060 s; and $3-6.3{ }^{\circ} \mathrm{C}$ by 2090 s. The study suggested that annual precipitation will change by -34 to $+22 \%$ by $2030 \mathrm{~s}$; -36 to $+67 \%$ by 2060 s; and -43 to $+80 \%$ by 2090 s. A study by Khadka et al. (2014) in the Tamakoshi basin of Nepal using multiple GCMs and scenarios showed that average temperature and precipitation will increase in future at the rate of $0.025{ }^{\circ} \mathrm{C} /$ year and $4.7 \mathrm{~mm} /$ year respectively. Similarly, study by WECS (2014) in the Koshi basin suggested that annual mean temperature will increase by $1.4{ }^{\circ} \mathrm{C}, 1.6{ }^{\circ} \mathrm{C}$ and $2.3{ }^{\circ} \mathrm{C}$ in $2030 \mathrm{~s}$ (2030-2039), 2040s (2040-2049) and 2050s (20502059) and annual precipitation will change by $-3,+2$ and $+5 \%$ during the same period compared to 1981-2010. It also suggests that winter precipitation is projected to decrease in future period while summer precipitation will increase.

Water and its availability and quality will be the main pressures on, and issues for, societies and the environment under climate change (IPCC 2007). Climate change is likely to alter hydrological cycle of the catchment which will result in increased climatic variability. Bradley et al. (2006) found the rate of increase of temperature is more in the higher altitude, hence it suggests the basin originating in the Himalayas is likely to have higher impacts of climate change. IPCC (2013) has suggested that global mean surface temperature in the near-term future (2016-2035) compared to reference period of 1986-2005 will be in the range of 0.3 to $0.7{ }^{\circ} \mathrm{C}$. Similarly, the area encompassed by monsoon systems will increase over the 21 st century and monsoon season is likely to intensify due to the increase in atmospheric moisture. Monsoon onset dates are likely to become earlier or not to change much. Monsoon retreat dates will likely be delayed, resulting in lengthening of the monsoon season in many regions. As the IPCC has released the output of latest global circulation model (GCM) data for climate change projection which encapsulate wider range of scenario, updated climate science and climate models, it is imperative to produce updated climate projection in basin level so that it can form a basis for impact analysis and adaptation for different sectors.

\section{Study area}

The study has been conducted in the Marshyandi basin of Nepal (Fig. 1). It is located between $27^{\circ} 50^{\prime} 42^{\prime \prime} \mathrm{N}$ to $28^{\circ}$ $54^{\prime} 11^{\prime \prime} \mathrm{N}$ latitudes and $83^{\circ} 47^{\prime} 24^{\prime \prime} \mathrm{E}$ to $84^{\circ} 48^{\prime} 04^{\prime \prime} \mathrm{E}$ longitudes. The basin has a total area of 4,787 sq. $\mathrm{km}$. of which about 2,150 sq. $\mathrm{km}$. (45 \%) lies above the elevation of 4,000 masl. The elevation of the basin varies between 200 masl to 7,800 masl. Physiographically, the basin extends from High Himalaya in the north to Lesser Himalayan region in the south (Shrestha \& Aryal, 2011). Administratively, the study area lies in four districts namely, Manang, Lamjung, Gorkha and Tanahu. The Marsyangdi river originating from this basin is a tributary of the Narayani River system which ultimately confluence with the Ganges River. The Marsyangdi basin is an important river basin in Nepal from Hydropower perspective. At present, two hydropower projects namely Marsyangdi Hydropower Project (69 MW) and Middle Marsyangdi Hydroelectric Project (70 MW) are operating in the basin. Further, Upper Marsyangdi Hydroelectric Project (600 MW), Lower Manang Marsyangdi Hydroelectric Project (100 MW) and Nyadi Hydropower Project $(30 \mathrm{MW})$ are under different stages of development.

The climate in the study area is predominately governed by the summer monsoon, which extends from June to September. Due to the high relief of the basin, general climate varies from sub-tropical in the lower belt to arctic in the higher altitudes. Hypsometric distribution of area in the basin is shown in Fig. 2.

\section{Methods}

\section{Observed climatic data}

The study makes use of observed meteorological data acquired from Department of Hydrology and Meteorology (DHM), Nepal. DHM is the sole organization responsible for collection and dissemination of meteorological and hydrological information in the country. It has established and maintained network of hydro-meteorological stations across the country. Daily meteorological data of Marsyangdi basin has been collected from DHM for available period (Table 1, Fig. 3).

\section{Climate change projections}

Climate change projection for future has been made using Second Generation Canadian Earth System Model (CanESM2) developed by Canadian Centre for Climate Modeling and Analysis (CCCma) (Salzen et al. 2013; Arora et al. 2011). CanESM2 consists of fourth generation atmospheric general circulation model (CGCM4) and the fourth generation ocean general circulation model (OGCM4). It is a climate simulation performed within the framework of Climate Model Inter-comparison Project Phase 5 (CMIP 5) which contributes to the fifth assessment report of the IPCC. 


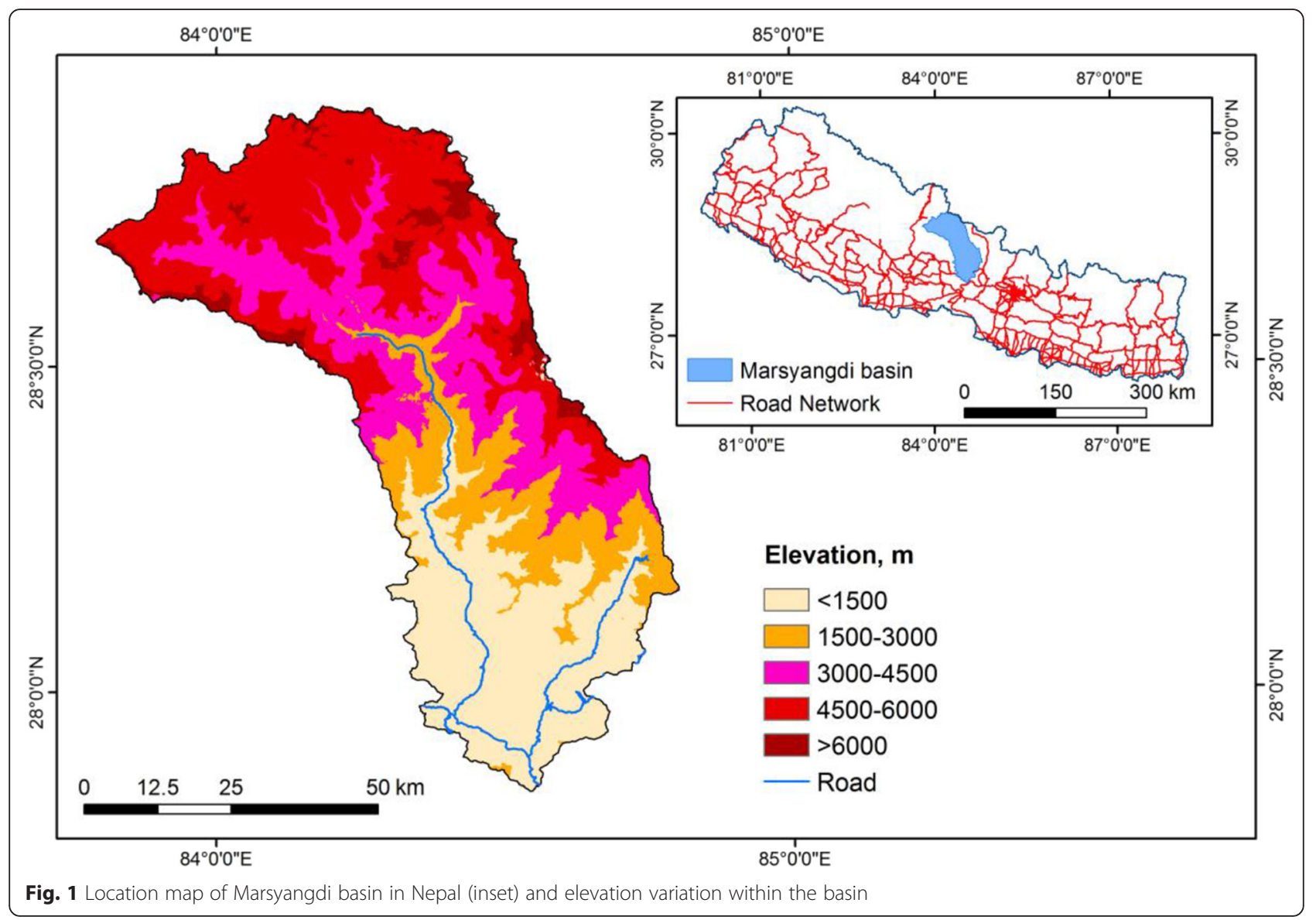

IPCC in its fifth assessment report have used a new set of scenarios called Representative Concentration Pathways (RCPs) (Vuuren, et al. 2011, Moss, et al. 2010) based on a set of scenarios of anthropogenic forcings which are used for the new climate model simulations carried out under the framework of the CMIP 5. RCPs have been developed using Integrated Assessment Models (IAMs) that typically include economic, demographic, energy and simple climate components. Before AR5, IPCC has been using climate change scenario based on Special Report on Emission Scenarios (SRES) published in 2000 (IPCC Working Group III 2000). In contrast to the AR4, the climate change from the RCP scenarios in the AR5 is framed as a combination of adaptation and mitigation (IPCC 2013). They produce a

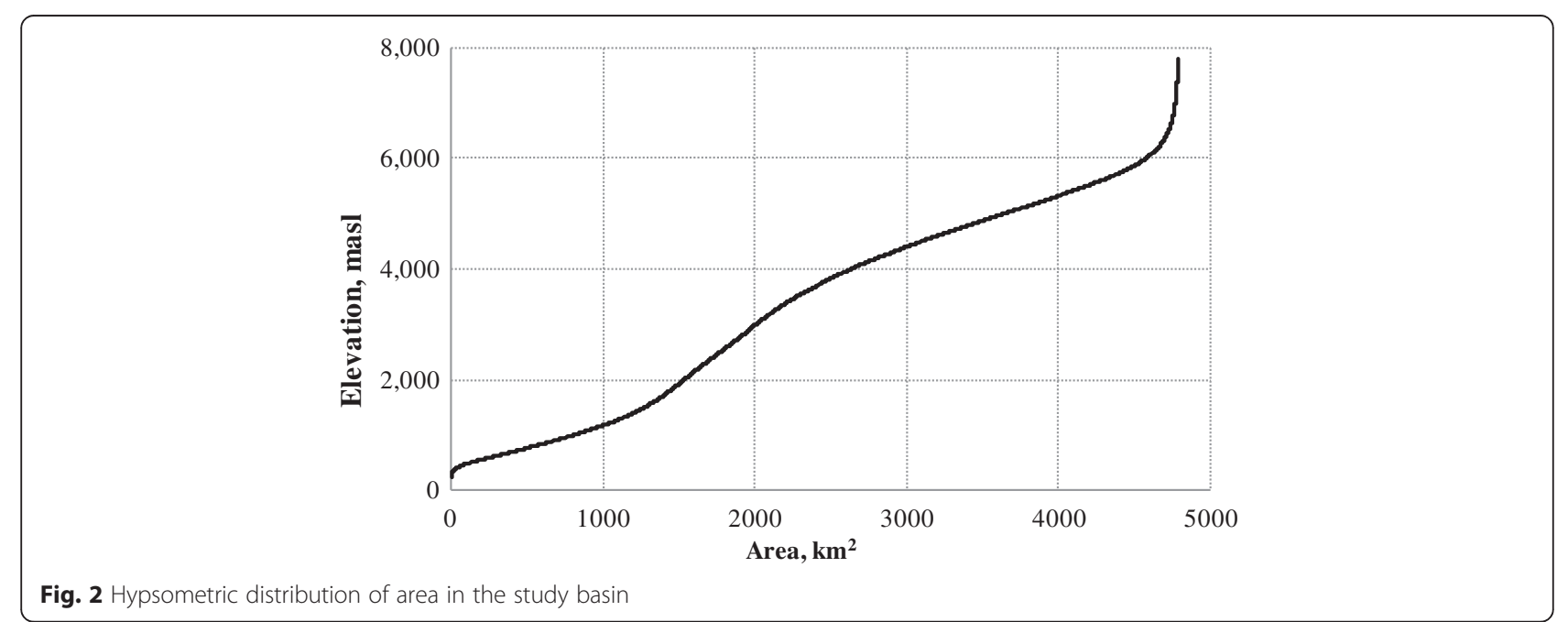


Table 1 List of meteorological stations used in the study

\begin{tabular}{|c|c|c|c|c|c|c|c|c|}
\hline SN & Station ID & Station name & District & Latitude & Longitude & Altitude, masl & Period & Data Available \\
\hline 1 & 608 & Ranipauwa & Mustang & $28^{\circ} 49^{\prime} 12^{\prime \prime}$ & $83^{\circ} 52^{\prime} 48^{\prime \prime}$ & 3,609 & 1969-2010 & Precipitation \\
\hline 2 & 802 & Khudi bazar & Lamjung & $28^{\circ} 16^{\prime} 48^{\prime \prime}$ & $84^{\circ} 22^{\prime} 12^{\prime \prime}$ & 823 & 1957-2009 & Precipitation, Temperature \\
\hline 3 & 806 & Larke samdo & Gorkha & $28^{\circ} 40^{\prime} 12^{\prime \prime}$ & $84^{\circ} 37^{\prime} 12^{\prime \prime}$ & 3,650 & 1978-2010 & Precipitation \\
\hline 4 & 807 & Kunchha & Lamiung & $28^{\circ} 7^{\prime} 48^{\prime \prime}$ & $84^{\circ} 20^{\prime} 60^{\prime \prime}$ & 855 & $1957-2010$ & Precipitation \\
\hline 5 & 808 & Bandipur & Tanahun & $27^{\circ} 55^{\prime} 48^{\prime \prime}$ & $84^{\circ} 25^{\prime} 12^{\prime \prime}$ & 965 & 1956-2009 & Precipitation \\
\hline 6 & 809 & Gorkha & Gorkha & $28^{\circ} 0^{\prime} 0^{\prime \prime}$ & $84^{\circ} 37^{\prime} 12^{\prime \prime}$ & 1,097 & 1956-2009 & Precipitation, Temperature \\
\hline 7 & 816 & Chame & Manang & $28^{\circ} 33^{\prime} 0^{\prime \prime}$ & $84^{\circ} 13^{\prime} 48^{\prime \prime}$ & 2,680 & 1974-2009 & Precipitation, Temperature \\
\hline 8 & 820 & Manang bhot & Manang & $28^{\circ} 40^{\prime} 12^{\prime \prime}$ & $84^{\circ} 1^{\prime} 12^{\prime \prime}$ & 3,420 & 1975-2010 & Precipitation \\
\hline 9 & 823 & Gharedhunga & Lamjung & $28^{\circ} 12^{\prime} 0^{\prime \prime}$ & $84^{\circ} 37^{\prime} 12^{\prime \prime}$ & 1,120 & 1976-2010 & Precipitation \\
\hline
\end{tabular}

range of responses from ongoing warming, to approximately stabilize forcing, to a stringent mitigation scenario that stabilizes and then slowly reduces the RF after mid21 st century. Four RCPs have been used in AR5 to represent future scenarios. They are RCP 2.6, RCP 4.5, RCP 6 and RCP 8.5. In all RCPs, atmospheric $\mathrm{CO}_{2}$ concentrations are higher in 2100 relative to present day as a result of a further increase of cumulative emissions of $\mathrm{CO}_{2}$ to the atmosphere during the 21st century. RCP 2.6 (van Vuuren et al. 2006; van Vuuren et al. 2007) is a low emission scenario where Radiative forcing (RF) reaches $3.1 \mathrm{~W} / \mathrm{m}^{2}$ before it returns to $2.6 \mathrm{~W} / \mathrm{m}^{2}$ by 2100 ; RCP 4.5 (Smith and Wigley 2006; Clarke et al. 2007; Wise et al. 2009) is an intermediate emission scenario where RF stabilizes shortly after year 2100 to $4.5 \mathrm{~W} / \mathrm{m}^{2}$; RCP 6 (Fujino et al. 2006; Hijioka et al. 2008) is also an intermediate emission

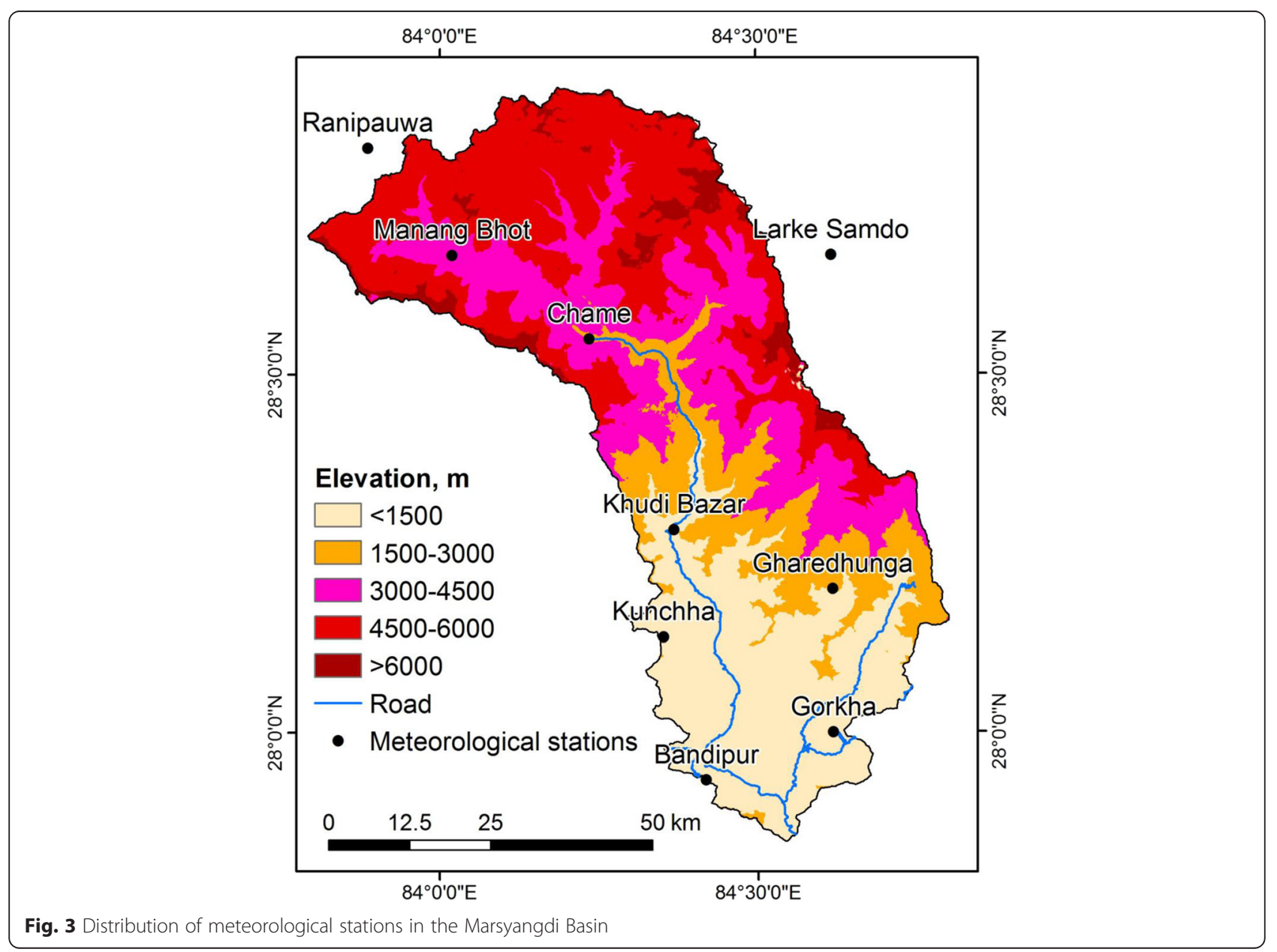



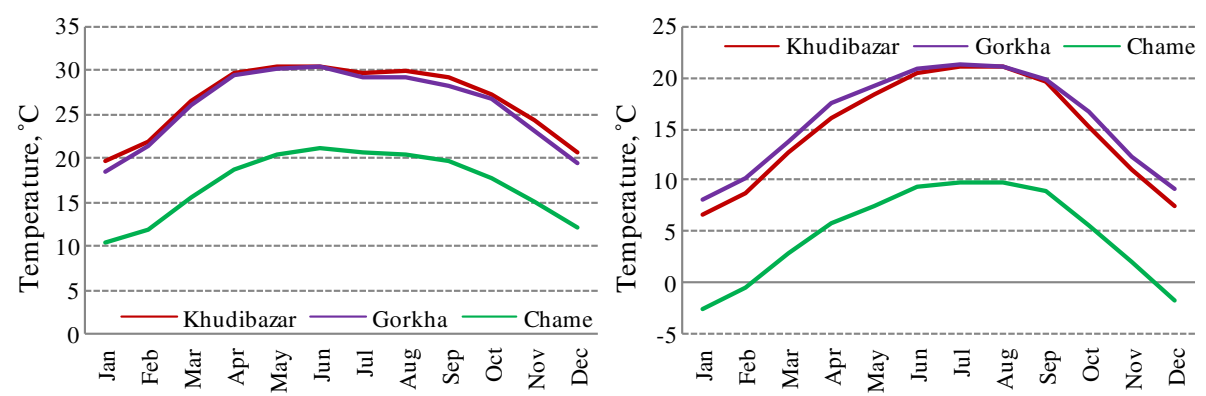

Fig. 4 Monthly distribution of maximum temperature (left) and minimum temperature (right)

scenario in which RF stabilizes after 2100 to $6 \mathrm{~W} / \mathrm{m}^{2}$. RCP 8.5 (Riahi et al. 2007; Rao and Riahi 2006) is a high emission scenario which has rising RF leading to $8.5 \mathrm{~W} / \mathrm{m}^{2}$ by 2100 .

The climate change scenario provided by CanESM2 is available at a grid size of $2.8125^{\circ}$. The data available at this resolution is not suitable for hydrological analysis and thus highlights the necessity of downscaling so that it can be useful for basin scale analysis. GCMs in general are unable to resolve the sub-grid and regional climate scenarios and fail to take into account important regional features such as topography, vegetation, cloudiness which govern the local climate. Hence it is important to downscale the GCM data from global scale to local scale (Khadka et al. 2014). In the study, GCM outputs at global scale has been statistically downscaled to a point scale. Statistical downscaling involves a technique in which a linear transfer fucntions between meso-scale atmospheric predictors variables of GCM (e.g. mean sea level pressure, geo-potential height, specific humidity etc.) and local climatic variables (temperature, precipitation etc.) are developed for observed period and these transfer functions are used to derive a point scale climate projections for future period. For this purpose, SDSM version 4.2 (Wilby and Dawson 2007) has been used for statistical downscaling. Several reserachers have used SDSM for downscaling GCM data to a point scale (Khadka et al. 2014; Pervez and Henebry 2014; Babel et al. 2013; Mahmood and Babel 2013). CanESM2 provides GCM projections for three RCPs (RCP 2.6, RCP 4.5 \& RCP 8.5) for the period of 2006 to 2100 along with NCEP data for 1961 to 2005. The observed data from 1961 to 1995 has been used for the calibration and 1996 to 2005 for the validation. Future climate change projection is divided into three periods, namely 2030s (20112040), 2060s (2041-2070) and 2090s (2071-2100).

To remove any systematic bias in the downscaled climate projection data, bias correction using long term monthly mean has been applied. Temperature data has been corrected by addition of difference between mean monthly observed temperature and SDSM simulated mean monthly temperature for observed period. Similarly, precipitation data is corrected by multiplying with ratio of mean monthly observed precipitation and SDSM simulated mean monthly precipitation (Teutschbein and Seibert 2012). Equations (1) and (2) have been used for bias corrections.

$$
\begin{aligned}
& T_{B C}=T_{S C E N}+\left(\overline{T_{O B S}}-\overline{T_{C O N T}}\right) \\
& P_{B C}=P_{S C E N} \times\left(\frac{\overline{P_{O B S}}}{\overline{P_{C O N T}}}\right)
\end{aligned}
$$

Where, $T_{B C}$ and $P_{B C}$ are bias corrected daily temperature and precipitation respectively, $\mathrm{T}_{\text {SCEN }}$ and $\mathrm{P}_{\text {SCEN }}$ are daily temperature and precipitation downscaled using SDSM. $\overline{T_{O B S}} \& \overline{P_{O B S}}$ are long term monthly mean of observed temperature and precipitation respectively, while $\overline{T_{C O N T}} \& \overline{P_{C O N T}}$ are long term monthly mean of temperature and precipitation simulated using SDSM for the observed period.
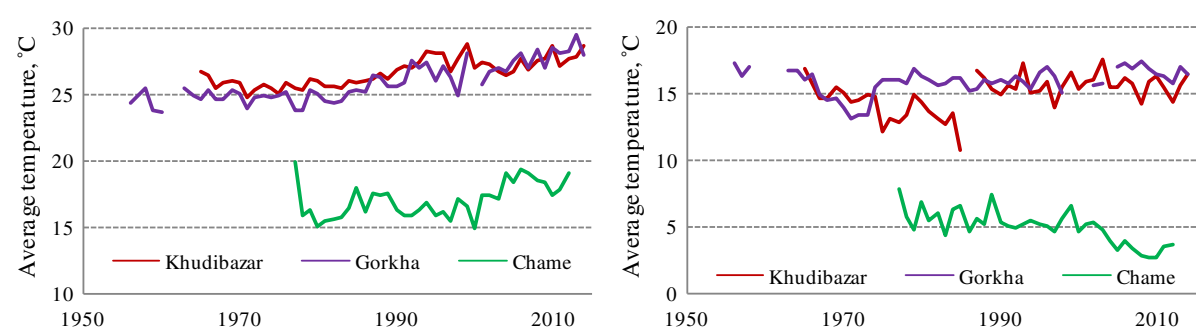

Fig. 5 Maximum temperature trend (left) and Minimum temperature trend (right) in Marsyangdi basin 


\section{Results and discussions}

\section{Observed precipitation and temperature}

Temperature information is available in three stations (Chame, Gorkha and Khudi bazar) in the study area. The monthly distribution of maximum and minimum temperature recorded in those stations shows that maximum temperature is highest in the basin during April to June while the minimum temperature is highest during July and August (Fig. 4). Temperature has been recorded below $0{ }^{\circ} \mathrm{C}$ in Chame station from December to February.

Annual average trend of maximum and minimum temperature shows that in general, maximum temperature over the observed period indicates stronger increasing trend than minimum temperature (Fig. 5). Among the stations, maximum temperature has increasing trend of $0.061{ }^{\circ} \mathrm{C}$ /year in Chame, $0.07{ }^{\circ} \mathrm{C} /$ year in Gorkha and $0.054{ }^{\circ} \mathrm{C} /$ year in Khudi bazar stations. Minimum temperature has shown decreasing trend in Chame $\left(-0.08{ }^{\circ} \mathrm{C} /\right.$ year $)$ while increasing trend of $0.034{ }^{\circ} \mathrm{C} /$ year in Gorkha and $0.018{ }^{\circ} \mathrm{C} /$ year in Khudi bazar stations.

Precipitation data has been collected for the nine stations within and adjacent to the Marsyangdi basin. The elevation of these stations varies from 800 masl to 3,600 masl and the recorded precipitation has also shown great variations (annual rainfall between $800 \mathrm{~mm}$ to $3,200 \mathrm{~mm}$ ). The comparison between variation of annual precipitation with elevation shows that stations which are at the elevation of around 1,000 masl show greater variation in annual precipitation between $1,500 \mathrm{~mm}$ to $3,500 \mathrm{~mm}$; while stations which are above 2,000 masl, have annual precipitation below 1,000 mm (Fig. 6).

Average monthly distribution of the precipitation in the study area has been derived using Theissen's polygon method (Fig. 7). As the general climate is governed by summer monsoon, period of June to September receives highest precipitation, which accounts for about $76 \%$ of annual precipitation $(1,700 \mathrm{~mm})$. The seasonal distribution of the rainfall in the meteorological stations in the

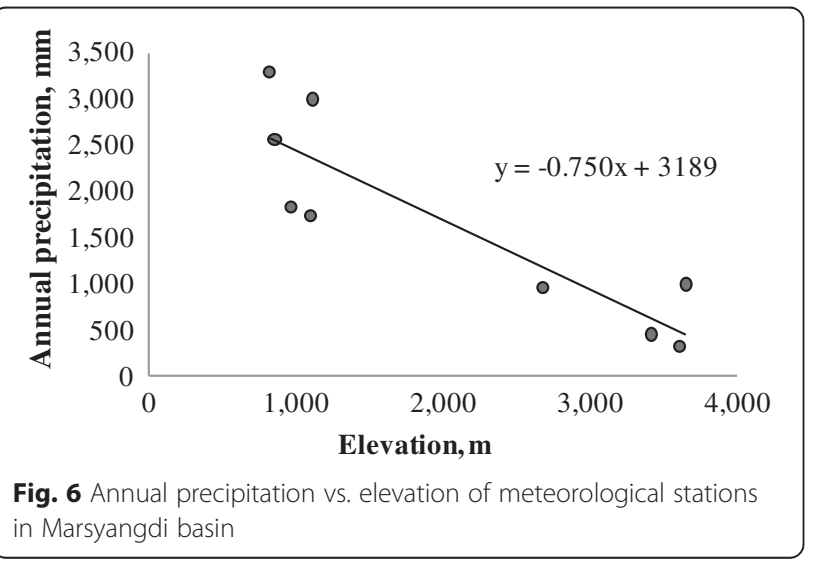

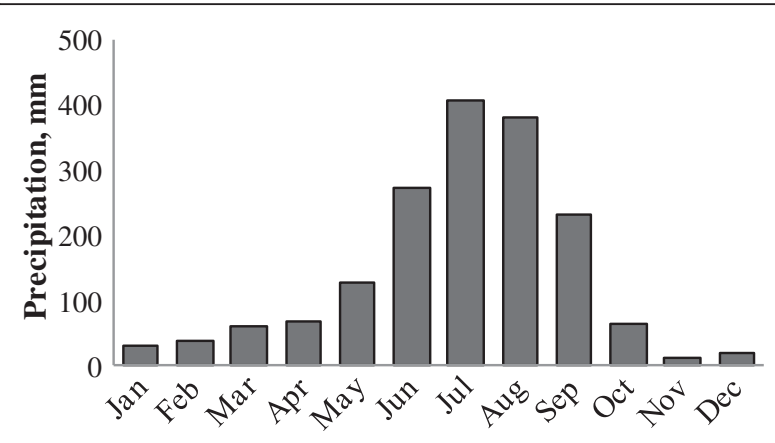

Fig. 7 Monthly distribution of precipitation in the Marsyangdi basin

Marsyangdi basin has been assessed (Table 2). Seasons are defined as winter (December, January and February), spring (March, April and May), summer (June, July, August and September) and autumn (October and November).

It is observed that summer season receives highest precipitation followed by spring, while winter and autumn period receive lowest precipitation. Annual precipitation trend observed in the meteorological stations shows that stations located in the central region of the basin have increasing trend while those at boundaries have slightly decreasing trend (Fig. 8.). Highest increasing trend is observed in station at Gharedhunga $(13.5 \mathrm{~mm} /$ year) while highest decreasing trend in observed at Larke Samdo (-20 $\mathrm{mm} /$ year). The station at Larke Samdo is located outside the Marsyangdi basin.

\section{Future climatic projections}

Calibration and validation of data downscaled using SDSM

Calibration is a process of developing a regression relationship between large scale predictor variables of GCM with local predictand variables. There are 26 predictor variables available from GCM and among them only few variables have significant relationship with the predictor variable. Therefore, screening of predictor variables has

Table 2 Seasonal observed precipitation in the meteorological stations

\begin{tabular}{lllllll}
\hline SN & Station name & \multicolumn{7}{l}{ Precipitation, mm } \\
\cline { 3 - 7 } & & Winter & Spring & Summer & Autumn & Annual \\
\hline 1 & Ranipauwa & 32 & 36 & 223 & 16 & 308 \\
2 & Khudi bazar & 85 & 381 & 2,665 & 117 & 3,248 \\
3 & Larke Samdo & 185 & 240 & 474 & 64 & 964 \\
4 & Kunchha & 67 & 401 & 1,968 & 110 & 2,547 \\
5 & Bandipur & 63 & 308 & 1,373 & 73 & 1,817 \\
6 & Gorkha & 55 & 275 & 1,330 & 58 & 1,718 \\
7 & Chame & 94 & 182 & 594 & 59 & 929 \\
8 & Manang Bhot & 58 & 84 & 222 & 43 & 407 \\
9 & Gharedhunga & 69 & 359 & 2,377 & 103 & 2,908 \\
\hline
\end{tabular}




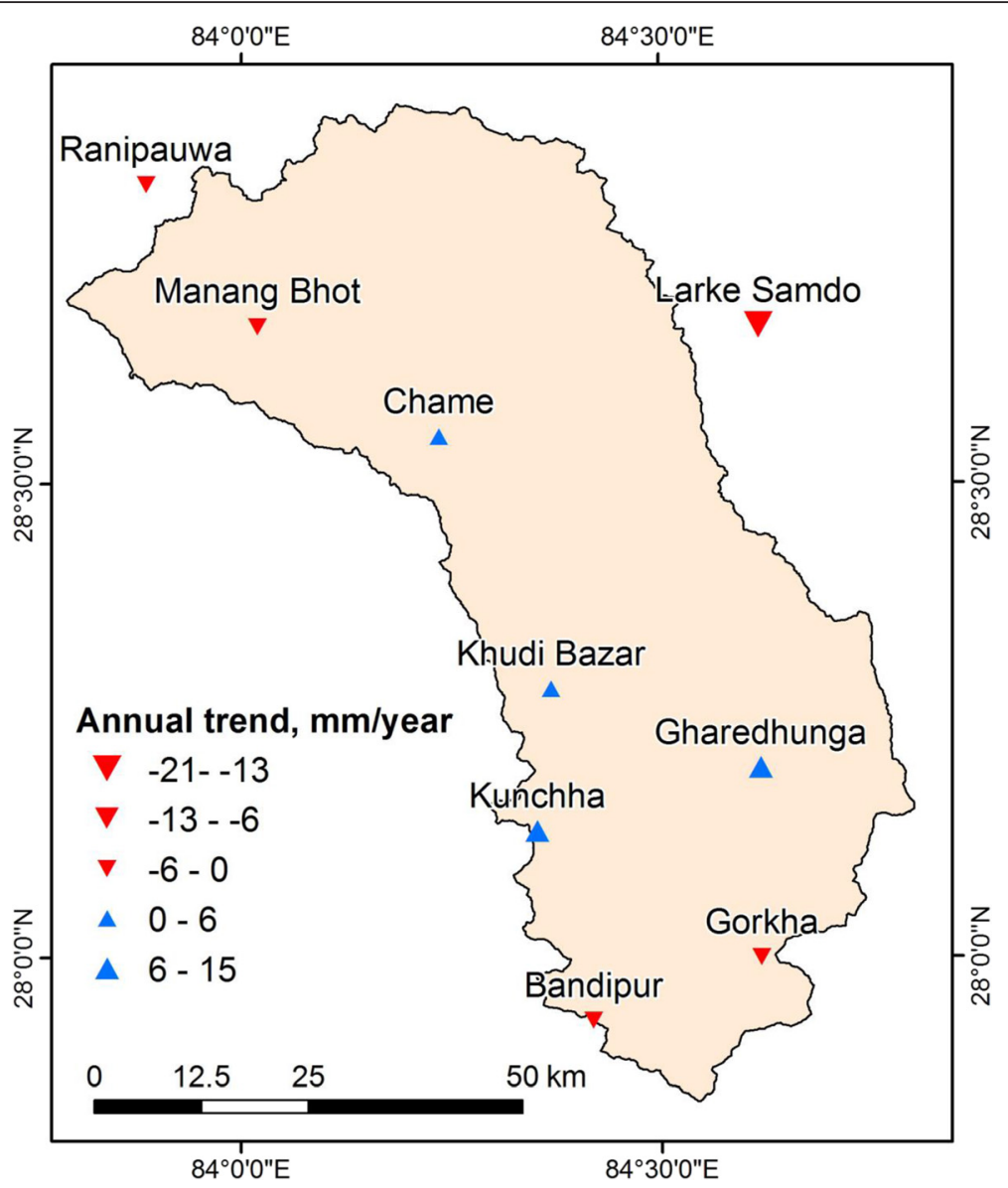

Fig. 8 Annual precipitation trend observed in the meteorological stations

been performed before calibrating the model, which is a central to all statistical downscaling (Wilby 2002). The method described by Mahmood and Babel (2013) has been followed in this study. A combination of the correlation matrix, partial correlation and $\mathrm{P}$ value at significance level of 0.05 has been considered. The predictor variable having highest correlation coefficient has been chosen as 'super predictor variable'. Among remaining predictor variables, which have good correlation coefficient with the predictand, partial correlation coefficient in presence of super predictor variable has been calculated along with percentage reduction in an absolute correlation using following equation.

$$
P R P=\left(\frac{P \cdot r-R 1}{R 1}\right)
$$

Where PRP is the percentage reduction in partial correlation with respect to the correlation coefficient, P.r is the partial correlation coefficient, and $R 1$ is the correlation coefficient between the predictor and predictand. Predictand variable which has high multi co-linearity with the super predictor variable is avoided.
The selected predictor variables for temperature and precipitation downscaling at Gorkha station along with Partial R is presented in Table 3. SDSM model has been calibrated for the period of 1961 to 1995 using these predictor variables. For assessing the reliability of the calibrated model, the simulated result is validated by comparing it with the observed period of 1996 to 2005 . Figures 9 and 10 shows the comparison of observed and

Table 3 Screened predictor variables for temperature and precipitation at Gorkha station

\begin{tabular}{llr}
\hline $\begin{array}{l}\text { Predictand } \\
\text { variables }\end{array}$ & Predictor variables (NCEP Reanalysis) & Partial R \\
\hline Max. Temperature & $500 \mathrm{hPa}$ Geopotential height (ncepp500gl) & 0.709 \\
& $500 \mathrm{hPa}$ Specific humidity (nceps500gl) & 0.586 \\
Min. Temperature & $500 \mathrm{hPa}$ Geopotential height (ncepp500gl) & 0.773 \\
& Surface Specific humidity (ncepshumgl) & 0.783 \\
& Air temperature at 2 m (nceptempgl) & 0.865 \\
Precipitation & Mean Sea Level Pressure (ncepmslpgk) & -0.183 \\
& Surface meridional wind velocity & 0.115 \\
& (ncepp1_vgl) & \\
& Total Precipitation (ncepprcpgl) & 0.174 \\
\hline
\end{tabular}


a

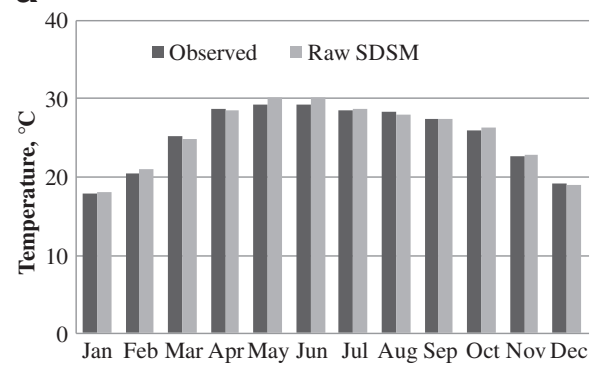

C

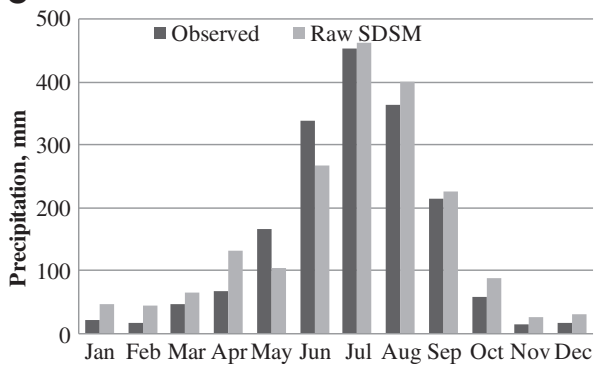

b

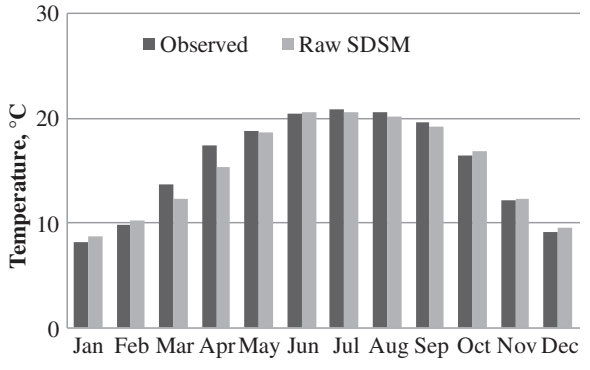

Fig. 9 Comparison of observed and simulated maximum temperature at Gorkha station

simulated temperature and precipitation during calibration and validation period for Gorkha station. Summary of statistical performance of the model is presented in Table 4. For maximum and minimum temperature, coefficient of determination $\left(R^{2}\right)$ is above 0.95 which is a good result. For precipitation, $R^{2}$ is 0.88 during calibration and
0.79 during validation. Precipitation simulation is complicated as it is a conditional process and daily precipitation amount is poorly resolved by regional-scale predictors (Wilby and Dawson, 2007). However, as the standard deviation of simulated precipitation is close to the observed along with reasonable $R^{2}$, model performance can be
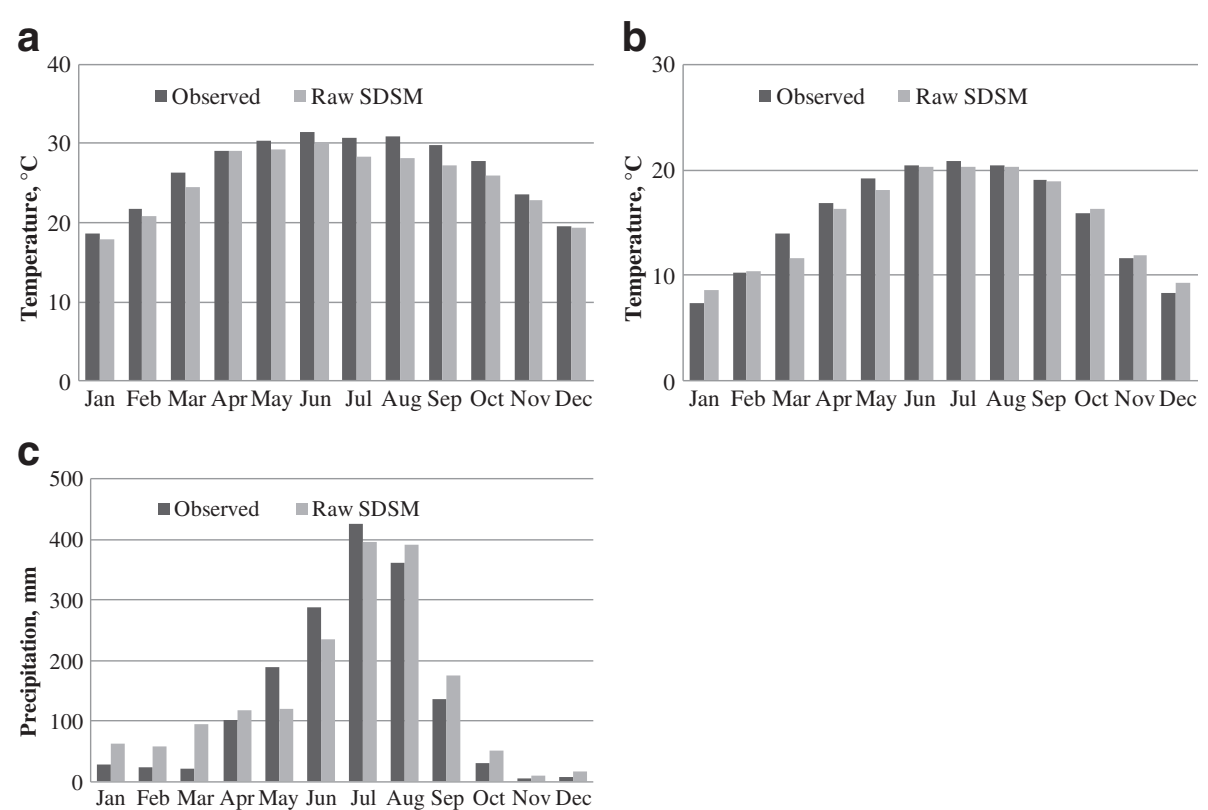

Fig. 10 Comparison of observed and simulated maximum temperature (a), minimum temperature (b), and precipitation (c) for validation period at Gorkha station 
Table 4 Statistical performance of simulated results compared to the observed data at Gorkha Station

\begin{tabular}{|c|c|c|c|c|c|}
\hline & & \multicolumn{2}{|c|}{ Calibration period (1961-1995) } & \multicolumn{2}{|c|}{ Validation period (1996-2005) } \\
\hline & & Observed & Simulated & Observed & Simulated \\
\hline \multirow[t]{2}{*}{ Max. Temperature } & Std Dev $\left({ }^{\circ} \mathrm{C}\right)$ & 4.16 & 4.26 & 4.61 & 4.21 \\
\hline & $R^{2}$ & - & 0.98 & - & 0.96 \\
\hline \multirow[t]{2}{*}{ Min. Temperature } & Std Dev $\left({ }^{\circ} \mathrm{C}\right)$ & 4.77 & 4.53 & 4.94 & 4.58 \\
\hline & $R^{2}$ & - & 0.97 & - & 0.96 \\
\hline \multirow[t]{2}{*}{ Precipitation } & Std Dev (mm) & 157.73 & 161.83 & 148.83 & 138.80 \\
\hline & $R^{2}$ & - & 0.88 & - & 0.79 \\
\hline
\end{tabular}

considered satisfactory. The output of SDSM is subjected to bias correction using long term monthly mean to remove any systematic bias.

Outputs of CanESM2 have been downscaled using SDSM for three RCPs to project future temperature and precipitation. Maximum and minimum temperature has been downscaled for available three stations (Chame, Gorkha and Khudi bazar). The projected change in maximum and minimum temperature for three future periods from three RCPs, compared to the baseline period of 1976-2005 is presented in Table 5. The results show that for RCP 4.5 and RCP 8.5, both maximum and minimum temperature will continue to rise in future while for RCP 2.6, temperature will increase up to 2060s and slightly decrease afterwards. This suits well with the assumptions of RCP 2.6 where RF will reach $3.1 \mathrm{~W} / \mathrm{m}^{2}$ before it returns to $2.6 \mathrm{~W} / \mathrm{m}^{2}$ by 2100 . Annual average increase in maximum and minimum temperature in three stations shows that in 2030s, increment in temperature for all RCPs are comparable, however by 2090s, RCP 8.5 has projected maximum increase in both maximum and minimum temperature (Fig. 11). By 2090s, RCP 2.6 has projected increase in temperature from $0.8^{\circ} \mathrm{C}$ to $1{ }^{\circ} \mathrm{C}$, for RCP 4.5, it is from $1.2^{\circ} \mathrm{C}$ to $1.5^{\circ} \mathrm{C}$ and for RCP 8.5 , from $2.1^{\circ} \mathrm{C}$ to $2.6{ }^{\circ} \mathrm{C}$.

In general, projected increase in minimum temperature is slightly higher than the maximum temperature. For $\mathrm{RCP} 8.5$, annual average of minimum temperature is projected to increase by $2.43{ }^{\circ} \mathrm{C}$ compared to baseline, while maximum temperature is projected to increase by $2.29^{\circ} \mathrm{C}$ in same period.

Projected average increase in seasonal temperature shows that highest increase in maximum temperature has been projected for spring for all RCPs, which is followed by autumn (Fig. 12). In 2090s, maximum temperature is projected to increase by $2.8^{\circ} \mathrm{C}$ in spring and $2.5{ }^{\circ} \mathrm{C}$ in autumn for RCP 8.5. Similarly, for RCP 4.5, it is projected to increase by $1.7{ }^{\circ} \mathrm{C}$ and $1.5{ }^{\circ} \mathrm{C}$ in spring and autumn respectively; while for RCP 2.6 , projected increase is $1.0^{\circ} \mathrm{C}$ for both seasons. Winter has least projected increment in maximum temperature. Similarly, highest increase in minimum temperature is projected for autumn which is followed by spring. Winter has least projected increase in minimum temperature. For RCP 8.5, projected increase in minimum temperature in 2090s in autumn and spring is $3.3{ }^{\circ} \mathrm{C}$ and $3.1{ }^{\circ} \mathrm{C}$, respectively. For RCP 4.5 , it is projected to increase by $2.0{ }^{\circ} \mathrm{C}$ and $1.9{ }^{\circ} \mathrm{C}$ for respective seasons for same period; while for RCP 2.6 , it is $1.4{ }^{\circ} \mathrm{C}$ and $0.8{ }^{\circ} \mathrm{C}$, respectively.

Long term precipitation data available for nine stations in and adjacent to Marsyangdi basin has been used for future projections. The projected annual precipitation in nine meteorological stations for three future periods, compared to the baseline period of 1976-2005 is presented in Table 6. It is found that precipitation will decrease in three of the above mentioned stations in future period under three RCPs compared to the baseline while for other stations, it is projected to increase. Projected decrease in

Table 5 Projected change in maximum and minimum temperature for three RCPs

\begin{tabular}{|c|c|c|c|c|c|c|c|c|c|c|c|c|}
\hline \multirow[t]{2}{*}{ Stations } & \multirow[t]{2}{*}{ Temp } & \multirow[t]{2}{*}{ Baseline, ${ }^{\circ} \mathrm{C}$} & & \multicolumn{3}{|c|}{ RCP 2.6} & \multicolumn{3}{|c|}{ RCP 4.5} & \multicolumn{3}{|c|}{ RCP 8.5} \\
\hline & & & & $2030 \mathrm{~s}$ & $2060 \mathrm{~s}$ & $2090 \mathrm{~s}$ & $2030 \mathrm{~s}$ & $2060 \mathrm{~s}$ & $2090 \mathrm{~s}$ & $2030 s$ & $2060 \mathrm{~s}$ & $2090 \mathrm{~s}$ \\
\hline \multirow[t]{2}{*}{ Chame } & Max & 16.45 & Projected change, ${ }^{\circ} \mathrm{C}$ & 0.68 & 1.02 & 0.88 & 0.70 & 1.19 & 1.44 & 0.89 & 1.59 & 2.50 \\
\hline & Min & 5.13 & & 0.70 & 1.01 & 0.86 & 0.72 & 1.20 & 1.40 & 0.82 & 1.54 & 2.37 \\
\hline \multirow[t]{2}{*}{ Gorkha } & Max & 25.76 & & 0.87 & 1.07 & 1.04 & 0.89 & 1.22 & 1.43 & 0.95 & 1.53 & 2.28 \\
\hline & Min & 15.76 & & 0.75 & 0.96 & 0.79 & 0.66 & 1.10 & 1.43 & 0.83 & 1.49 & 2.36 \\
\hline \multirow[t]{2}{*}{ Khudi bazar } & Max & 26.64 & & 0.49 & 0.71 & 0.52 & 0.47 & 0.96 & 1.18 & 0.64 & 1.33 & 2.10 \\
\hline & Min & 14.68 & & 0.84 & 1.09 & 0.95 & 0.84 & 1.33 & 1.49 & 0.94 & 1.70 & 2.57 \\
\hline
\end{tabular}



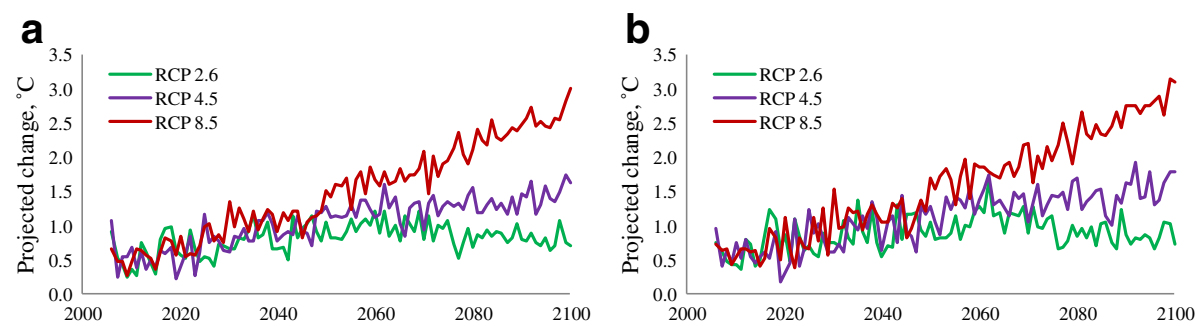

Fig. 11 Projected change in (a) maximum temperature, and (b) minimum temperature compared to baseline period

annual rainfall is up to $-10 \%$ while increment is up to $30 \%$ of the baseline period. It is noted that stations in which annual precipitation has been projected to decrease in future are at the elevation above 3,400 masl. The projected change in precipitation vs. elevation of meteorological stations for three RCPs shows that generally, the projected increase in precipitation has inverse relation with the elevation (Fig. 13). Stations in lower elevation have higher percentage increase in projected precipitation while stations in the higher altitude have lesser or decrease in projected precipitation. The projected annual average precipitation for the Marsyangdi basin for three RCPs is shown in Fig. 14. Towards the end of the 21st century, projected increase for RCP 8.5 is highest while RCP 2.6 is lowest, though before 2050, all RCPs have similar projections. For RCP 4.5 , projected annual precipitation is between RCP 2.6 and RCP 8.5.

Seasonal change in projected precipitation for future period, compared to the baseline period shows that that autumn season has highest projected percentage increase in precipitation for all RCPs (Fig. 15). For RCP 2.6, precipitation during spring is projected to slightly decrease while for other seasons, it is projected to increase. Annual precipitation is projected to increase by 3-4 \% for all three future periods. For RCP 4.5, annual precipitation is projected to increase by 7,13 , and $14 \%$ in 2030s, 2060s and 2090s, respectively. RCP 8.5 has highest percentage increase in projected precipitation

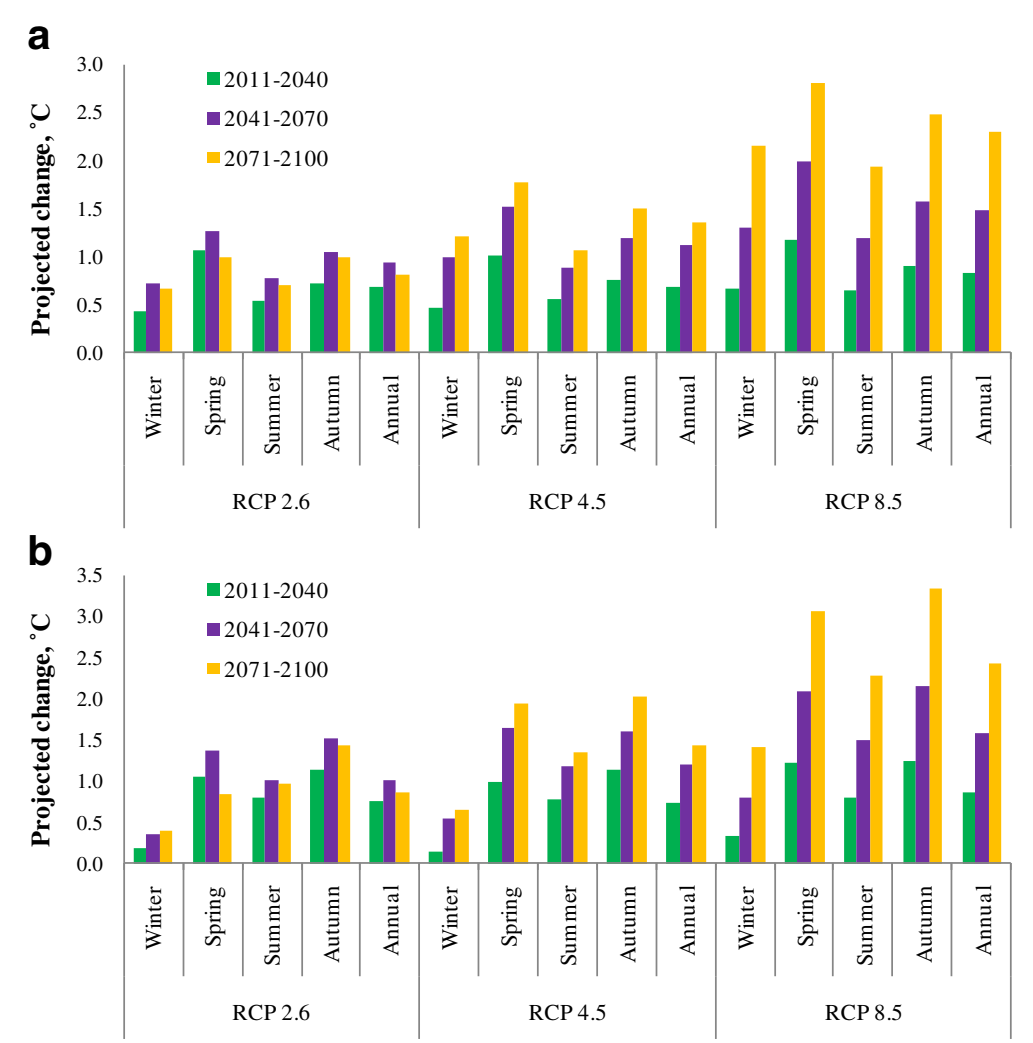

Fig. 12 Seasonal projected change in (a) maximum temperature, and (b) minimum temperature, compared to the baseline 
Table 6 Projected change in annual precipitation for future periods compared to baseline under three RCPs

\begin{tabular}{|c|c|c|c|c|c|c|c|c|c|c|c|c|}
\hline \multirow[t]{2}{*}{ SN } & \multirow[t]{2}{*}{ Stations } & \multirow{2}{*}{$\begin{array}{l}\text { Annual precipitation } \\
\text { in baseline period, } \mathrm{mm}\end{array}$} & & \multicolumn{3}{|c|}{ RCP 2.6} & \multicolumn{3}{|c|}{ RCP 4.5} & \multicolumn{3}{|c|}{ RCP 8.5} \\
\hline & & & & $2030 \mathrm{~s}$ & $2060 s$ & $2090 \mathrm{~s}$ & $2030 \mathrm{~s}$ & $2060 \mathrm{~s}$ & 2090s & 2030s & $2060 \mathrm{~s}$ & $2090 \mathrm{~s}$ \\
\hline 1 & Larke samdo & 1,081 & $\%$ change compared to baseline & $-7 \%$ & $-10 \%$ & $-8 \%$ & $-3 \%$ & $-3 \%$ & $-2 \%$ & $-1 \%$ & $-4 \%$ & $-7 \%$ \\
\hline 2 & Ranipauwa & 284 & & $-3 \%$ & $0 \%$ & $0 \%$ & $0 \%$ & $1 \%$ & $-6 \%$ & $-6 \%$ & $-7 \%$ & $-6 \%$ \\
\hline 3 & Manang bhot & 461 & & $0 \%$ & $-3 \%$ & $-6 \%$ & $-4 \%$ & $-3 \%$ & $-3 \%$ & $-6 \%$ & $0 \%$ & $-1 \%$ \\
\hline 4 & Chame & 932 & & $9 \%$ & $3 \%$ & $12 \%$ & $8 \%$ & $11 \%$ & $13 \%$ & $11 \%$ & $5 \%$ & $15 \%$ \\
\hline 5 & Gharedhunga & 2,992 & & $0 \%$ & $3 \%$ & $1 \%$ & $16 \%$ & $18 \%$ & $18 \%$ & $18 \%$ & $18 \%$ & $25 \%$ \\
\hline 6 & Gorkha & 1,731 & & $7 \%$ & $2 \%$ & $4 \%$ & $-3 \%$ & $12 \%$ & $11 \%$ & $4 \%$ & $10 \%$ & $22 \%$ \\
\hline 7 & Bandipur & 1,743 & & $15 \%$ & $4 \%$ & $8 \%$ & $2 \%$ & $14 \%$ & $19 \%$ & $9 \%$ & $10 \%$ & $15 \%$ \\
\hline 8 & Kunchha & 2,616 & & $5 \%$ & $5 \%$ & $3 \%$ & $2 \%$ & $13 \%$ & $11 \%$ & $6 \%$ & $14 \%$ & $17 \%$ \\
\hline 9 & Khudi bazar & 3,362 & & $5 \%$ & $9 \%$ & $8 \%$ & $6 \%$ & $12 \%$ & $17 \%$ & $8 \%$ & $14 \%$ & $30 \%$ \\
\hline
\end{tabular}

during autumn and lowest during winter. Annual average precipitation is projected to increase by 10,12 , and $21 \%$ in 2030s, 2060s and 2090s, respectively.

For assessing projected change in extreme precipitation in future, 99th percentile precipitation during summer season has been considered in the study. Extreme precipitation events have high significance in context of water induced disasters like floods and landslides which are frequent during summer in the study area. Table 7 presents the comparison of 99th percentage exceedance precipitation in future with baseline period. In most of the stations, 99th percentile exceedance precipitation has been projected to increase in future for all RCPs (except in Manang Bhot \& Bandipur for RCP 2.6). Maximum increase has been projected in Gorkha, Ranipauwa and Larke Samdo. It is noted that even in the stations where annual precipitation is projected to decrease in future, 99th percentile exceedance precipitation has been projected to increase. It suggests that in future, magnitude and frequency of extreme precipitation events will increase.

\section{Climate change implication in geodisasters}

The change in precipitation scenario with more intense rainstorms due to climate change has direct and indirect impact in various sectors, including the geodisasters. Studies in Swiss Alps have revealed that the increase in the overall magnitude of debris flows is expected with the increase in extreme precipitation events, which can be attributed to climate change (Stoffel et al. 2014). Likewise, the studies have shown that increasing rainfall due to climate change will also increase soil erosion in the Himalayas (Khare et al. 2016). Record shows that there has been series of landslide, flood and avalanche disaster

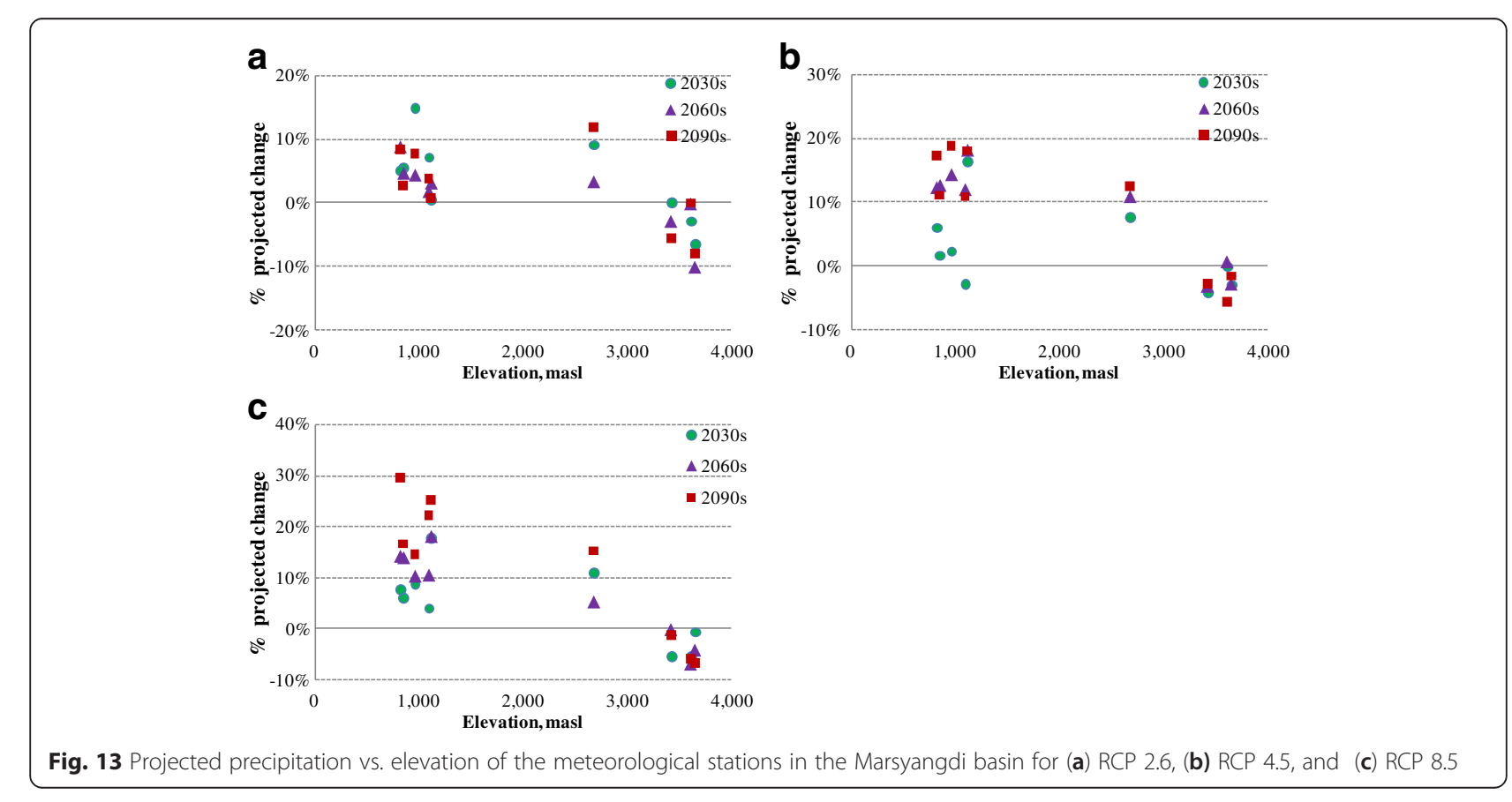




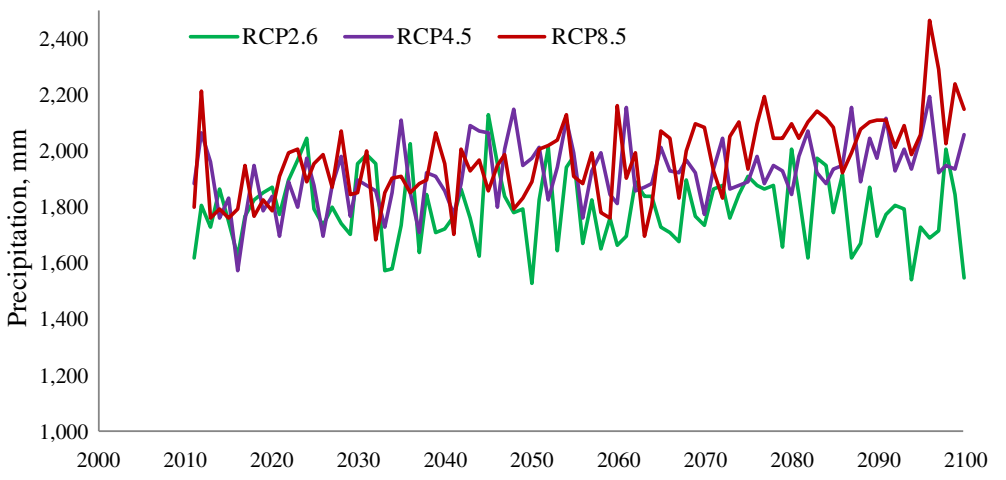

Fig. 14 Projected annual precipitation compared to baseline period for three RCPs

in the Marsyangdi basin. The northern part of the basin is situated in Manang district that is not only affected by avalanche problem but also flood disaster. For example, in Thoche and Dharapani village development committees, the area was affected by flood in 1996, 2006 and 2009 that destroyed dozens of houses (UNISDR 2011). Similar was the case of flood disasters in Bhujung village of Lamjung and Barpak village of Gorkha districts. There were ten human casualties in Bhujung village in 1973 while the Barpak village witnessed eight people missing in 1999 flood. As far as the casualties and damages due to landslide are considered, it is widespread in the basin. Dharapani, Chame and Bhraka villages in Manang district, Simpani, Nalma and Bahundada villages in Lamjung district and Palungtar village in Gorkha district are some of the cases that faced human casualties and destruction of houses due to landslide. These examples indicates that geodisasters are common in the study area, which is expected to increase in future with the pronounced climate change leading to either increased precipitation or change in nature of precipitation to low duration high intensity. The projected increased precipitation from the present climate model delineates the areas to be considered for mitigation and adaptation measures so as to cope with the adverse situation in future thereby reducing the disaster risk.

\section{Conclusion}

The future climate projection for the Marsyangdi basin has been carried out using the outputs of CanESM2 developed by Canadian Centre for Climate Modeling and Analysis (CCCma). The result from this model is also included in the fifth assessment report (AR5) of IPCC. Compared to fourth assessment report (AR4) of IPCC, several improvements in terms of understanding of climate science, better simulation of climate models and representation of future scenarios have been achieved in AR5. An important development since the AR4 is the more widespread use of Earth System Models (ESMs), which include an interactive carbon cycle. Similarly, compared to AR4, more detailed observations and improved climate models now enable the attribution of detected changes to human influences in more climate system components. Previous assessment report by IPCC (AR3 \& AR4) used SRES scenarios while AR5 has made use of Representative Concentration Pathways (RCPs) which is framed as a combination of adaptation

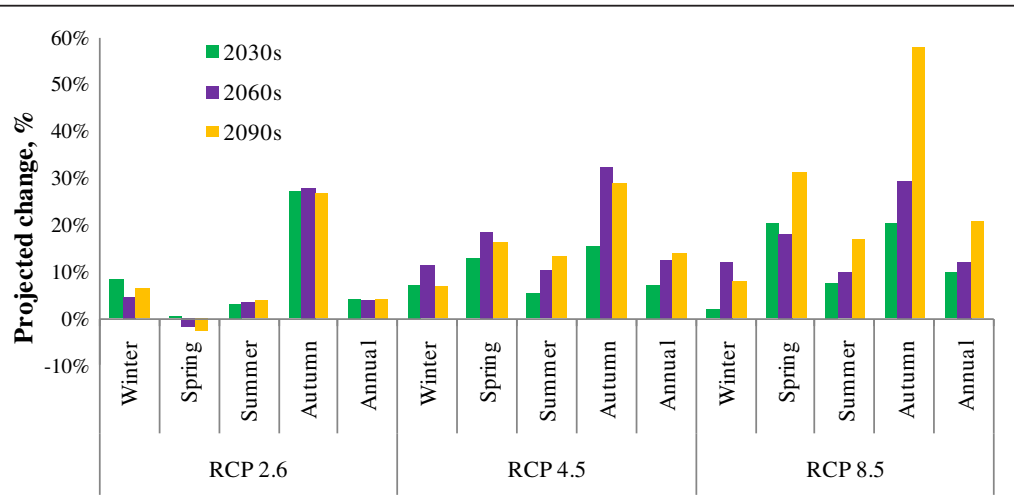

Fig. 15 Seasonal change in projected precipitation compared to baseline period 
Table 7 Projected change in 99th percentile summer precipitation for future period compared to baseline under three RCPS

\begin{tabular}{|c|c|c|c|c|c|c|c|c|c|c|c|c|}
\hline \multirow[t]{2}{*}{ SN } & \multirow[t]{2}{*}{ Stations } & \multirow{2}{*}{$\begin{array}{l}99 \text { percentile exceedance } \\
\text { precipitation during } \\
\text { baseline, } \mathrm{mm}\end{array}$} & & \multicolumn{3}{|l|}{ RCP 2.6} & \multicolumn{3}{|c|}{ RCP 4.5} & \multicolumn{3}{|c|}{ RCP 8.5} \\
\hline & & & & $2030 \mathrm{~s}$ & $2060 s$ & $2090 \mathrm{~s}$ & $2030 \mathrm{~s}$ & $2060 \mathrm{~s}$ & $2090 \mathrm{~s}$ & $2030 s$ & $2060 s$ & $2090 \mathrm{~s}$ \\
\hline 1 & Larke Samdo & 25 & \% change compared to baseline & $21 \%$ & $28 \%$ & $28 \%$ & $42 \%$ & $43 \%$ & $45 \%$ & $30 \%$ & $25 \%$ & $32 \%$ \\
\hline 2 & Ranipauwa & 14 & & $37 \%$ & $47 \%$ & $44 \%$ & $46 \%$ & $45 \%$ & $34 \%$ & $46 \%$ & $48 \%$ & $51 \%$ \\
\hline 3 & Manang Bhot & 23 & & $-13 \%$ & $-10 \%$ & $0 \%$ & $-5 \%$ & $-7 \%$ & $-4 \%$ & $-7 \%$ & $2 \%$ & $1 \%$ \\
\hline 4 & Chame & 30 & & $26 \%$ & $16 \%$ & $12 \%$ & $21 \%$ & $23 \%$ & $25 \%$ & $19 \%$ & $23 \%$ & $23 \%$ \\
\hline 5 & Gharedhunga & 114 & & $6 \%$ & $4 \%$ & $1 \%$ & $11 \%$ & $9 \%$ & $17 \%$ & $8 \%$ & $9 \%$ & $5 \%$ \\
\hline 6 & Gorkha & 78 & & $42 \%$ & $38 \%$ & $25 \%$ & $35 \%$ & $47 \%$ & $47 \%$ & $26 \%$ & $32 \%$ & $47 \%$ \\
\hline 7 & Bandipur & 96 & & $9 \%$ & $-7 \%$ & $-2 \%$ & $0 \%$ & $4 \%$ & $8 \%$ & $-1 \%$ & $6 \%$ & $9 \%$ \\
\hline 8 & Kunchha & 120 & & $-1 \%$ & $5 \%$ & $1 \%$ & $0 \%$ & $3 \%$ & $0 \%$ & $2 \%$ & $12 \%$ & $8 \%$ \\
\hline 9 & Khudi bazar & 122 & & $8 \%$ & $8 \%$ & $5 \%$ & $16 \%$ & $13 \%$ & $12 \%$ & $14 \%$ & $11 \%$ & $11 \%$ \\
\hline
\end{tabular}

and mitigation. The simulation of large-scale patterns of precipitation has improved somewhat since the AR4 and substantial progress in model simulations of extreme events have been achieved since the AR4. The outputs of CanESM2 are available in large grid size $\left(2.8125^{\circ}\right)$ which is too coarse for basin level study. Hence, the outputs have been downscaled to station level using statistical downscaling model (SDSM). Projection of future temperature and precipitation is carried out for three RCPs which cover large spectrum of scenarios and compared with baseline period of 1976-2005.

The projection of maximum and minimum daily temperature for Marsyangdi basin shows that for all RCPs, future temperature will be higher than in the baseline period of $1976-2005$. RCP 2.6, which is a stringent mitigation scenario, projects that temperature will increase till 2060s and then slightly decrease towards 2090s. For this scenario, maximum and minimum temperatures are projected to increase by $0.82{ }^{\circ} \mathrm{C}$ and $0.87^{\circ} \mathrm{C}$ by 2090 s respectively, compared to baseline. For 2060s, they are projected to increase by $0.97{ }^{\circ} \mathrm{C}$ and $1.02{ }^{\circ} \mathrm{C}$. Similarly, RCP 4.5 which is an intermediate emission scenario, has steady increase and maximum and minimum temperatures are projected to increase by $1.35{ }^{\circ} \mathrm{C}$ and $1.44{ }^{\circ} \mathrm{C}$ in 2090s. For $\mathrm{RCP} 8.5$, which is a high emission scenario, temperature will continue to rise in future and by 2090s, maximum and minimum temperatures are projected to increase by $2.29{ }^{\circ} \mathrm{C}$ and $2.43{ }^{\circ} \mathrm{C}$, respectively. On seasonal basis, highest increase for maximum temperature is projected in spring season followed by autumn while for minimum temperature, highest increment is projected in autumn followed by spring. For the high emission scenario of RCP 8.5 , in 2090s, projected increase for maximum temperature in spring is by $2.8^{\circ} \mathrm{C}$ while for minimum temperature, projected increase in autumn is by $3.33^{\circ} \mathrm{C}$.

Future projections of precipitation data in the Marsyangdi basin show that precipitation will decrease slightly in future in the meteorological station above the elevation of 3,400 masl while it will increase in other stations. It is found that projected increase in precipitation in future has inverse relationship with the elevation, i.e. stations in lower elevation have higher projected increase. For RCP 2.6, projected increase in annual average precipitation for all future period is about 3-4\% compared with the baseline. Seasonally, precipitation during spring is projected to slightly decrease in future while highest percentage increase is projected during autumn. Similarly, annual average precipitation for RCP 4.5 is projected to increase by 7,13 and $14 \%$ in 2030s, 2060s and 2090s, respectively. RCP 8.5 has highest projected increase in annual precipitation which is by 10,12 and $21 \%$ in 2030s, 2060s and 2090s, respectively. Seasonally, highest percentage increase is projected for autumn followed by spring season. In terms of extreme precipitation, 99th percentile exceedance precipitation for summer season has been considered in the analysis. Among the nine meteorological stations considered, seven stations show increase in magnitude of 99th percentile exceedance precipitation in future for all RCPs while two stations show increase only for RCP 8.5. Even in the stations where annual precipitation has been projected to decrease, magnitude of this 99th percentile precipitation is projected to increase. It is an indication that in future extreme precipitation events will have higher magnitude and frequency. Compared to baseline period, 99th percentile precipitation is projected to increase in average by 13, 20 and $21 \%$ in 2090s for RCP 2.6, RCP 4.5 and RCP 8.5 , respectively.

Thus, the study suggests that temperature and precipitation will increase in future in Marsyangdi basin, compared to the baseline period. The band of projection between RCP 2.6 and RCP 8.5 has provided general range of this increment which will be determined by socio-economic and emission pathways in future. In general, along with rise in temperature, in average, climate change is likely to increase water availability in the Marsyangdi basin as suggested by projected increase in the average precipitation. The change in climatic condition will have serious implications in various geological 
disasters in the basin, which is already facing such disasters even without the effect of climate change. Therefore, the outcome of the present study can be a basis for future planning towards mitigation and adaptation to reduce the impact of climate change induced geodisasters in the basin.

\section{Abbreviations}

${ }^{\circ} \mathrm{C}$, degree centigrade; $\mathrm{AR}$, assessment report; AR5, fifth assessment report; Can ESM2, second generation Canadian earth system model; CCCma, Canadian centre for climate modeling and analysis; CMIP, climate model inter-comparison project; DHM, Department of hydrology and meteorology; GCM, global circulation model; IAM, integrated assessment model; ICEM, International centre for environmental management; IPCC, intergovernmental panel on climate change; $\mathrm{m}$, Metre; MASL, metre above sea level; mm, millimetre; MoSTE, ministry of science, technology and environment; MW, mega watt; NCEP, National centers for environmental prediction; NCVST, Nepal climate vulnerability study team; OECD, organization of economic co-operation and development; OGCM4, fourth generation ocean general circulation model; RCP, representative concentration pathway; RF, radiative forcing; SDSM, statistical downscaling model; SRES, special report on emission scenarios; WECS, water and energy commission secretariat; WWF, world wide fund for nature

\section{Acknowledgements}

This paper is based on research financed under the Climate Change Research Grants Program implemented by the Nepal Academy of Science and Technology. The Program is part of the Mainstreaming Climate Change Risk Management in Development project. This project is a component of Nepal's Pilot Program for Climate Resilience and is executed by the Ministry of Science, Technology and Environment, (Nepal), financed by the Climate Investment Funds, administered by the Asian Development Bank with technical assistance from ICEM, METCON and APTEC. Authors would like to thank Department of Hydrology and Meteorology (DHM) Nepal for providing climatic data records for the study and Central Department of Geology, Tribhuvan University for arranging required facilities to carry out the project related activities.

\section{Authors' contributions}

DK and DP collected the data, DK carried out the analysis of climate data, DP extended required suggestion and support on interpretation of the results. Both authors drafted and approved the final manuscript.

\section{Competing interests}

The authors declare that they have no competing interests.

\section{Received: 12 May 2016 Accepted: 26 July 2016}

Published online: 08 August 2016

\section{References}

Arora, V.K., J.F. Scinocca, G.J. Boer, J.R. Christian, K.L. Denman, G.M. Flato, V.V. Kharin, W.G. Lee, and W.J. Merryfield. 2011. Carbon emission limits required to satisfy future representative concentration pathways of greenhouse gases. Geophysical Research Letters 38(5): 3-8. doi:10.1029/2010GL046270.

Babel, M.S., S.P. Bhusal, S.M. Wahid, and A. Agrawal. 2013. Climate change and water resources in the bagmati river basin, Nepal. Theoretical and Applied Climatology 115(3): 639-654.

Bradley, S., M. Vuille, H. Diaz, and W. Vergara. 2006. Threats to water supplies in the tropical Andes. Science 312: 1755-1756. doi:10.1126/science.1128087.

Clarke, L., J. Edmonds, H. Jacoby, H. Pitcher, J. Reilly, and R. Richels. 2007. Scenarios of Greenhouse Gas Emissions and Atmospheric Concentrations Sub-report 21A of Synthesis and Assessment Product 21 by the US Climate Change Science Program and the Subcommittee on Global Change Research. Washington: Department of Energy, Office of Biological Environmental Research.

Fujino J, Nair R, Kainuma M, Masui T, Matsuoka, Y (2006) Multi-gas mitigation analysis on stabilization scenarios using AIM global model Multigas Mitigation and Cliamte Policy. The Energy Journal. Vol. Multi-Greenhouse Gas Mitigation and Climate Policy, Special Issue No.3, 343-354. doi:10.5547/ ISSN0195-6574-EJ-VoISI2006-NoSI3-17.
Hijioka, Y., Y. Matsuoka, H. Nishimoto, M. Masui, and M. Kainuma. 2008. Globa GHG emissions scenarios under GHG concentration stabilization targets. Journal of Global Environmental Engineering 13: 97-108.

IPCC. 2007. Climate Change 2007: The Physical Science Basis Contribution of Working Group I to the Fourth Assessment Report of the Intergovernmental Panel on Climate Change. [In: Solomon S, Qin D, Manning M, Marquis M, Averyt K, Tignor MM, and Miller, H.L. (Eds)] Cambridge University Press, Cambridge, United Kingdom and New York, NY, USA, p.996.

IPCC. 2013. Climate Change 2013: The Physical Science Basis Contribution of Working Group I to the Fifth Assessment Report of the Intergovernmental Panel on Climate Change. [In: Stocker T.F, Qin D, Plattner G.K, Tignor M.M, Allen S.K, Boschung J, Nauels A, Xia Y, Bex V. and Midgley P.M (Eds)] Cambridge University Press, Cambridge, United Kingdom and New York, NY, USA, p. 1535

IPCC Working Group III. 2000. IPCC special report emissions scenarios intergovernmental panel on climate change, Intergovernmental panel on climate change.

Khadka D, Babel M.S, Shrestha S, and Tripathi N.K. 2014. Climate change impact on glacier and snow melt and runoff in tamakoshi basin in the Hindu Kush Himalayan (HKH) region. Journal of Hydrology 511: 49-60.

Khare D, Mondal A, Kundu S, and Mishra PB. 2016. Climate change impact on soil erosion in the Mandakini River Basin, North India. Applied Water Science, doi: 10.1007/s13201-016-0419-y.

Mahmood, R., and M.S. Babel. 2013. Evaluation of SDSM developed by annual and monthly sub-models for downscaling temperature and precipitation in the Jhelum basin, Pakistan and India. Theoretical and Applied Climatology 113(1): 27-44.

Moss, R.H., J.A. Edmonds, K.A. Hibbard, M.R. Manning, S.K. Rose, D.P. van Vuuren, T.R. Carter, S. Emori, M. Kainuma, T. Kram, G.A. Meeh, J.F.B. Mitchel, N. Nakicenovic, K. Riahi, S.J. Smith, R.J. Stouffer, A.M. Thomson, J.P. Weyant, and T.J. Silbanks. 2010. The next generation of scenarios for climate change research and assessment. Nature 463: 747-756. doi:10.1038/nature08823.

MoSTE. 2014. Nepal climate change program (CCP) results management framework (RMF) 2013-2020 ministry of science, technology and environment.

NCVST. 2009. Vulnerability through the eyes of vulnerable: Climate change induced uncertainties and Nepal's Development Predicaments. Kathmandu: Institute for Social and Environmental Transition-Nepal (ISET-N, Kathmandu) and Institute for Social and Environmental Transition (ISET, Boulder, Colorado) for Nepal Climate Vulnereability Study Team (NCVST).

Pervez, M.S., and G.M. Henebry. 2014. Projections of the Ganges - Brahmaputra precipitation - downscaled from GCM predictors. Journal of Hydrology 517: 120-134. doi:10.1016/j.jhydrol.2014.05.016.

Rao, S., and K. Riahi. 2006. The role of non CO2 greenhouse gases in climate change mitigation: long-term scenarios for the 21 st century multigas mitigation and climate policy. The Energy Journal Vol. Multi-Greenhouse Gas Mitigation and Climate Policy 27(3): 177-200.

Riahi, K., A. Gruebler, and N. Nakicenovic. 2007. Scenarios of long-term socioeconomic and environmental development under climate stabilization. Technological Forecasting and Social Change 74(7): 887-935.

Salzen, K.V., J.F. Scinocca, N.A. McFarlane, J. Li, J.N. Cole, D. Plummer, et al. 2013. The Canadian fourth generation atmospheric global climate model (CanAM4) part l: representation of physical processes. Atmosphere-ocean.

Shrestha A.B, Aryal R. 2011. Climate change in Nepal and its impact on Himalayan glaciers. Regional Environmental Change, 65-77. doi: 10.1007/ s10113-010-0174-9

Smith, S.J., and T. Wigley. 2006. Multi-Gas forcing stabilization with the MiniCAM. The Energy Journal 3(Special Issue): 373-391.

Stoffel, M., T. Mendlik, M. Schneuwly-Bollschweiler, and A. Gobiet. 2014. Possible impacts of climate change on debris-flow activity in the Swiss Alps. Climatic Change 122: 141-155. doi:10.1007/s10584-013-0993-z.

Teutschbein, C., and J. Seibert. 2012. Bias correction of regional climate model simulations for hydrological climate-change impact studies: review and evaluation of different methods. J Hydrol 456-457: 12-29. doi:10.1016/j.jhydrol.2012.05.052.

UNISDR. 2011. DesInventar - a free, open source disaster information management system, UNISDR (http://www.desinventar.net/DesInventar/ profiletab.jsp?countrycode=npl). Accessed 28 June 2016.

van Vuuren, D., M. den Elzen, P. Lucas, B. Eickhout, B. Strengers, S. van Ruijen, S. Wonink, and R. van Houdt. 2007. Stabilizing greenhouse gas concentrations at low levels: an assessment of reduction strategies and costs. Climate Change 81(2): 119-159. doi:10.1007/s10584-006-9172-9.

van Vuuren, D. P J. Edmonds, M. Kainuma, K. Riahi, A. Thomson, K. Hibbard, G.C. Hurtt, T. Kram, V. Krey, L. Jean-Francois, T. Masui, M. Meinshausen, N. 
Nakicenovic, S.J. Smith, and S.K. Rose. 2011. The representative concentration pathways: an overview. Climate Change 109: 5-31. doi:10.1007/s10584-011-0148-z.

van Vuuren, D.P., B. Eickhout, P.L. Lucas, and M.G. den Elzen. 2006. Long-term multi-gas scenarios to stabilize radiative forcing - exploring costs and

benefits within an integrated assessment framework multigas mitigation and climate policy. The Energy Journal 3(Special Issue): 201-234

WECS. 2014. Study of impact of climate change in water induced disasters in river basins and their managment water and energy commission secretariat (WECS), Kathmandu.

Wilby, R.L., and C.W. Dawson. 2007. SDSM 4.2 - a decision support tool for the assessment of regional climate change impacts, user manual.

Wilby, R.L., C.W. Dawson, and E.M. Barrow. 2002. SDSM - a decision support tool for the assessment of regional climate impacts. Environ Model Software 17(2): 145-157.

Wise, M. K. Calvin, A. Thomson, L. Clarke, R. Sands, S.J. Smith, A. Janetos, and J. Edmonds. 2009. Implications of limiting CO2 concentrations for land use and energy. Science 324: 1183-1186.

WWF. 2005. An Overview of Glaciers, Glacier Retreat and subsequent Impacts in Nepal, India and China, WWF Nepal Program, World Wildlife Fund, Washington, D.C., p. 79. (https://www.wwf.or.jp/activities/lib/pdf_climate/ environment/Overview_of_Glaciers.pdf). Assessed 10 April 2016.

\section{Submit your manuscript to a SpringerOpen ${ }^{\odot}$ journal and benefit from:}

- Convenient online submission

- Rigorous peer review

- Immediate publication on acceptance

- Open access: articles freely available online

- High visibility within the field

- Retaining the copyright to your article

Submit your next manuscript at $\boldsymbol{s p r i n g e r o p e n . c o m ~}$ 